\title{
MODELS TO MINIMIZE OUTPUT OF MANURE-BEARING WASTEWATER FROM MILKING PARLOURS AT CONCEPTUAL DESIGNING STAGE OF DAIRY FARMS
}

\author{
Vladislav Gordeev, Tatiana Mironova, Victor Khazanov, Viacheslav Mironov \\ Federal Scientific Agroengineering Centre VIM, Russia \\ cow-sznii@yandex.ru,
}

\begin{abstract}
The main waste generated in the milking parlours is manure-bearing wastewater. Its amount governs the total volume of manure output from the farm and the costs of its storage, processing and disposal. The aim of the research was to create models to minimise the output of this wastewater at the conceptual designing stage of dairy farms. The relevant technological, technical and organizational factors were analysed. Based on regulatory data, the encoded regression equations were obtained by computation for the daily output of manure-bearing wastewater from the milking parlours with herringbone, parallel and carousel (rotary) milking installations depending on the technological group size, milking installation capacity, number of floor washings and the milking time of the herd. The number of floor washings was found to have the greatest effect on the specific output of manure-bearing wastewater. The encoded equations were also obtained for determining the maximum number of cows to be milked on one milking installation that also depended on the technological group size, the milking installation capacity, and the time of one milking of the herd. The obtained equations were used to find the optimal solutions at the conceptual designing stage, to choose the technological parameters of the cow barn and the milking parlour by the criterion of the minimum output of manure-bearing wastewater, and to reduce the anthropogenic load on the environment. For the herd of 600 heads with 5-hour milking twice a day, the minimum specific output of manure-bearing wastewater of $5.41 \cdot \mathrm{head}^{-1} \cdot \mathrm{day}^{-1}$ was estimated for the case of the herringbone milking installation. The technological group should be of 60 heads, and the installation should have 40 milking units.
\end{abstract}

Keywords: manure-bearing wastewater, designing, milking parlour, loose housing.

\section{Introduction}

Adequate technological solution, adopted at the designing stage of dairy farms, minimises the investment and resource costs and reduces the production waste, which needs to be stored, recycled and disposed of.

Cow milking is a key operation on dairy farms. The design of the milking parlour directly depends on the type and size of the milking installation. The studies of other authors examined the geometric parameters of milking parlours of various types [1]; estimated and optimised the milking process in terms of the milking time and unit costs [2]; developed a mathematical model to find the more cost-effective solution for the milking parlour and to evaluate the milking process efficiency for the farms to be built and for upgrading the existing farms with due account for technical parameters, job performance and economic criteria [3]; analysed the construction costs of milking parlours of various designs [4]. However, these indicators are not enough when designing a milking parlour. The growing attention is paid to production waste, which can be reduced already at the stage of spaceplanning decision-making.

On most livestock farms, the manure-bearing wastewater from the milking parlour is mixed with manure $[5 ; 6]$ affecting its total volume and storage, processing and disposal costs.

Manure-bearing wastewater from the milking parlour is a mix of animal excrement and the technological water, which is used to wash the exterior of the milking installation and for regular washing of the holding, milking and exit areas [7;8]. The output of manure-bearing wastewater depends on both quantitative and qualitative factors, which may be divided into technological (technological group size, number of floor washings, floor cleaning method), technical (type and size of the milking installation, floor cleaning equipment), and organizational (staff performance quality).

The holding area is governed by the technological group size. Under the same animal stock, the bigger number of cows in the group results in the bigger amount of produced manure-bearing wastewater, mainly due to the larger holding area [7]. Also, the waiting time in the holding area is longer and this has a negative effect on the level of cow comfort [9]. The type and size of the milking installation are selected by the number of lactating cows and estimated milking time of the herd; they affect the layout of the milking parlour, and, accordingly, the cleaning area. On some farms these areas are washed up to three times a day. Special equipment for preliminary floor cleaning and high- 
pressure washers contributes to significant water saving, and, consequently, smaller output of manurebearing wastewater [10]. The staff performance quality also affects the wastewater volume: high quality work helps reduce it, while low quality work and lack of control increase the required water consumption.

The aim of the research was to create models to minimise the output of manure-bearing wastewater from a milking parlour at the conceptual designing stage of dairy farms.

\section{Materialsandmethods}

The objective function to minimise the specific output of manure-bearing wastewater from the milking parlour per 1lactating cow $Y_{s p}$ may be written in the following form:

$$
Y_{s p}=f\left(X_{0}, X_{1}, X_{2}, X_{3}, X_{4}, X_{5}, X_{6}\right) \rightarrow \min ,
$$

where $Y_{s p}$ - specific output of manure-bearing wastewater from the milking parlour, $1 \cdot$ head $^{-1} \cdot$ day $^{-1}$

$X_{0}$ - milking installation type;

$X_{1}$ - technological group size, head;

$X_{2}$ - milking installation size, milking unit (stall);

$X_{3}$ - number of floor washings;

$X_{4}$ - milking time of the herd, hour;

$X_{5}$ - floor cleaning method;

$X_{6}-$ staff performance quality.

The above factors reflect the entire technological chain associated with generation of manurebearing wastewater from the milking parlour, suggesting a systematic approach to the phenomenon under study: variables $X_{1}$ and $X_{4}$ characterise the technological parameters of the farm, $X_{0}, X_{2}$ characterise the choice of equipment, $X_{3}, X_{5}$ show how the work is performed, and $X_{6}$ is an external factor.

The effect of some factors may be calculated [11]. Then, the specific output of manure-bearing wastewater from the milking parlour per head per day may be written as:

$$
Y_{s p}=\frac{Y_{\text {exc }}+Y_{\text {hoof }}+X_{3} Y_{\text {floor }}}{G}
$$

where $Y_{e x c}$ - volume of excrement, which gets into manure-bearing wastewater, $1 \cdot$ day $^{-1}$;

$Y_{\text {hoof }}-$ volume of solution for hoof treatment, $1 \cdot$ day $^{-1}$;

$Y_{\text {floor }}$ - volume of floor wash-water, which gets into manure-bearing wastewater, $1 \cdot$ day $^{-1}$;

$G$ - milking herd size, head.

The amount of excrement, left by the cows in the milking parlour, and the hoof treatment solution are calculated by the total number of animals [11].

Knowing the milking parlour area and the cleaning water requirement, the amount of generated wastewater is calculated. However, the effectiveness of this area use may be different and in terms of reducing the specific output of manure-bearing wastewater it may be determined by the number of milked cows:

$$
G=X_{1} \cdot n
$$

where $n$-number of technological groups, which can be milked on the milking installation. It depends on the throughput of the milking installation and the estimated milking time of the herd.

The maximum number of groups for each option may be found from the condition

$$
n \approx \frac{k t}{c}
$$

where $k$ - throughput coefficient of the milking installation, head $\cdot$ hour $^{-1}$ : herringbone -3.5 ; parallel - 4; carousel - 5;

$t$ - single milking time of the herd, hour; 
$c$ - coefficient of the occupancy rate of the milking installation (number of operation cycles of the milking installation per one group).

Coefficient $c$ for herringbone and parallel installations should take into account the technological group size: it is important that the number of cows in a group is a multiple of the number of milking units (stalls) located on one side of the operator's pit. For carousel this condition is not valid.

Coefficient $c$ for milking installations may be written as:

- herringbone and parallel $c=\frac{X_{1}}{X_{2}} c=\frac{X_{1}}{X_{2}}$, and rounded to the nearest larger multiple of 0.5;

- carousel $c=\frac{X_{1}+3}{X_{2}}$, where 3 is the number of vacant places when the groups rotate.

With this in mind, the expression (2) may be written as

$$
Y_{s p}=m_{\text {day }}+\frac{2 V_{\text {bath }}}{Q} \frac{q}{7}+\frac{X_{3} c V_{w}\left(S_{\text {holding }}+S_{\text {sanzone }}+S_{\text {parlour }}\right)}{X_{1} k t} ;
$$

where $m_{d a y}-$ average volume of excrement left in the milking parlour by one cow, $1 \cdot$ day $^{-1}$;

$V_{\text {bath. }}$ - volume of water in one hoof treatment bath, 1 ;

$Q$ - number of animals, after which the hoof treatment solution is replaced, head;

$q$ - number of hoof treatment days per week;

$V_{w}$ - volume of water used for regular floor washing, $1 \cdot \mathrm{m}^{-2}$;

$S_{\text {holding }}$ - holding area, $\mathrm{m}^{2}$;

$S_{\text {sanzone }}$ - sanitary zone area, $\mathrm{m}^{2}$;

$S_{\text {parlour }}$ - milking parlour area, $\mathrm{m}^{2}$.

Expression (5) requires the knowledge of coefficients and areas depending on the type and size of the milking installation that makes it poorly adapted for use. Therefore, it was converted for different types of milking installations.

The above factors were considered in such a way that the value coinciding with "minus 1 " level corresponded to the least favourable factor value for the target indicator, i.e. the greatest output of manure-bearing wastewater from the milking parlour; and "plus 1" - to the most favourable factor value, i.e. the lowest output of manure-bearing wastewater (Table 1).

Factors and their levels for different types of milking installations

Table 1

\begin{tabular}{|c|c|c|c|c|c|c|c|c|c|c|}
\hline \multirow{2}{*}{ Factor } & \multirow{2}{*}{ Symbol } & \multicolumn{10}{|c|}{ Factor levels } \\
\cline { 3 - 12 } & & \multicolumn{2}{|c|}{ Herringbone } & \multicolumn{3}{|c|}{ Parallel } & \multicolumn{3}{c|}{ Carousel } \\
\cline { 3 - 13 } & -1 & 0 & +1 & -1 & 0 & +1 & -1 & 0 & +1 \\
\hline $\begin{array}{c}\text { Technological group size, } \\
\text { head }\end{array}$ & $X_{1}$ & 180 & 120 & 60 & 180 & 120 & 60 & 300 & 180 & 60 \\
\hline $\begin{array}{c}\text { Milking installation size, } \\
\text { number of units (stalls) }\end{array}$ & $X_{2}$ & 40 & 30 & 20 & 60 & 40 & 20 & 90 & 55 & 20 \\
\hline Floor washings & $X_{3}$ & 3 & 2 & 1 & 3 & 2 & 1 & 3 & 2 & 1 \\
\hline Milking time, h & $X_{4}$ & 3.5 & 5 & 6.5 & 3.5 & 5 & 6.5 & 3.5 & 5 & 6.5 \\
\hline
\end{tabular}

The volume of manure-bearing wastewater generated in the milking parlour was calculated from the regulatory data and statistically average farming practices using the matrix of Box-Behnken design, which was generated using STATGRAPHICS Plus. The following values were used in the calculations: floor cleaning water in the milking parlour $-51 \cdot \mathrm{m}^{-2}$ [12]; the excrement left by cows in the milking parlour $-2 \%$ of their average daily output $\left(55 \mathrm{~kg} \cdot \mathrm{head}^{-1}\right)$ [13]; the hoof treatment twice a week [14] in two baths with the capacity of 2001 each: one with clean water to wash the hooves before the main treatment, and the other - with the treatment solution; the solution was changed after 250 cows had been treated $[14,15]$; the holding area of $2.0 \mathrm{~m}^{2} \cdot \mathrm{head}^{-1}[12]$; the milking parlour area 
was calculated by the method in [16]. In the study the size of the sanitary zone was neglected; the water for udder washing was also neglected, since on modern farms disposable wipes are used for this purpose.

\section{Results and discussion}

The calculated values of the specific output of manure-bearing wastewater are presented in Table 2.

Specific daily output of manure-bearing wastewater $\left(1 \cdot\right.$ head $\left.^{-1}\right)$

Table 2

\begin{tabular}{|c|c|c|c|c|c|c|c|c|c|c|c|c|c|}
\hline \multirow{3}{*}{ No. } & \multicolumn{4}{|c|}{$\begin{array}{c}\text { Coded values of } \\
\text { factors }\end{array}$} & \multirow{2}{*}{\multicolumn{3}{|c|}{$\begin{array}{c}\text { Maximum cow } \\
\text { number milked on } \\
\text { the milking } \\
\text { installation during } \\
\text { milking time } \mathrm{X}_{4}\end{array}$}} & \multicolumn{6}{|c|}{ 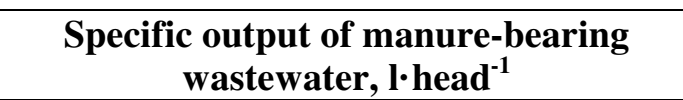 } \\
\hline & \multirow{2}{*}{ 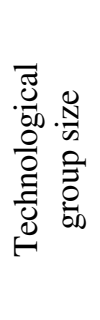 } & \multirow{2}{*}{ 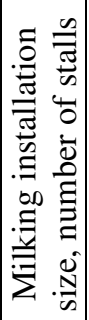 } & \multirow{2}{*}{ 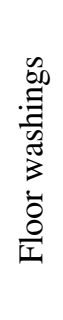 } & \multirow{2}{*}{ 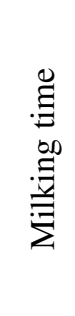 } & & & & \multicolumn{2}{|c|}{ Herringbone } & \multicolumn{2}{|c|}{ Parallel } & \multicolumn{2}{|c|}{ Carousel } \\
\hline & & & & & 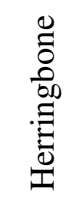 & 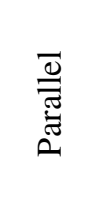 & 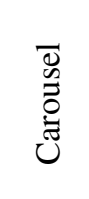 & 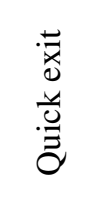 & 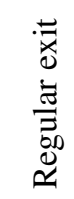 & 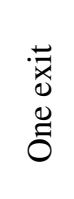 & $\begin{array}{l}\stackrel{n}{a} \\
0 \\
0 \\
0 \\
\overrightarrow{3}\end{array}$ & 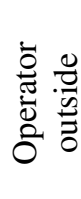 & 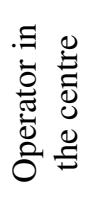 \\
\hline & $X_{1}$ & $X_{2}$ & $X_{3}$ & $X_{4}$ & $G_{1}$ & $G_{2}$ & $G_{3}$ & $Y_{1}$ & $Y_{2}$ & $Y_{3}$ & $Y_{4}$ & $Y_{5}$ & $Y_{6}$ \\
\hline 1 & 0 & 0 & 0 & 0 & 480 & 840 & 1440 & 11.8 & 9.2 & 7.4 & 7.0 & 5.7 & 5.9 \\
\hline 2 & -1 & -1 & 0 & 0 & 720 & 1260 & 2100 & 11.0 & 8.8 & 7.2 & 6.9 & 6.2 & 6.4 \\
\hline 3 & 1 & -1 & 0 & 0 & 720 & 1200 & 2160 & 7.7 & 5.5 & 5.4 & 5.1 & 3.9 & 4.1 \\
\hline 4 & -1 & 1 & 0 & 0 & 360 & 360 & 600 & 16.6 & 14.1 & 16.0 & 15.0 & 13.1 & 13.2 \\
\hline 5 & 1 & 1 & 0 & 0 & 360 & 420 & 480 & 9.9 & 7.4 & 8.2 & 7.4 & 6.0 & 6.2 \\
\hline 6 & 0 & 0 & -1 & -1 & 360 & 600 & 900 & 22.0 & 16.8 & 13.9 & 13.0 & 11.5 & 11.9 \\
\hline 7 & 0 & 0 & 1 & -1 & 360 & 600 & 900 & 8.4 & 6.6 & 5.7 & 5.4 & 4.9 & 5.0 \\
\hline 8 & 0 & 0 & -1 & 1 & 720 & 1080 & 1800 & 11.8 & 9.2 & 8.4 & 7.9 & 6.5 & 6.7 \\
\hline 9 & 0 & 0 & 1 & 1 & 720 & 1080 & 1800 & 5.0 & 4.1 & 3.8 & 3.7 & 3.2 & 3.3 \\
\hline 10 & -1 & 0 & 0 & -1 & 360 & 540 & 900 & 18.5 & 15.1 & 12.9 & 12.3 & 10.9 & 11.1 \\
\hline 11 & 1 & 0 & 0 & -1 & 360 & 540 & 900 & 11.8 & 8.4 & 8.5 & 7.8 & 5.5 & 5.8 \\
\hline 12 & -1 & 0 & 0 & 1 & 720 & 1080 & 1800 & 10.0 & 8.3 & 7.2 & 6.9 & 6.2 & 6.3 \\
\hline 13 & 1 & 0 & 0 & 1 & 660 & 1020 & 1680 & 7.2 & 5.3 & 5.2 & 4.9 & 3.7 & 3.8 \\
\hline 14 & 0 & 0 & 0 & 0 & 480 & 840 & 1440 & 11.8 & 9.2 & 7.4 & 7.0 & 5.7 & 5.9 \\
\hline 15 & 0 & -1 & -1 & 0 & 720 & 1200 & 2160 & 13.2 & 9.9 & 8.9 & 8.4 & 6.7 & 7.0 \\
\hline 16 & 0 & 1 & -1 & 0 & 360 & 360 & 540 & 19.1 & 15.3 & 18.2 & 16.8 & 14.2 & 14.4 \\
\hline 17 & 0 & -1 & 1 & 0 & 720 & 1200 & 2160 & 5.4 & 4.4 & 4.0 & 3.9 & 3.3 & 3.4 \\
\hline 18 & 0 & 1 & 1 & 0 & 360 & 360 & 540 & 7.4 & 6.1 & 7.1 & 6.6 & 5.8 & 5.8 \\
\hline 19 & -1 & 0 & -1 & 0 & 540 & 720 & 1500 & 18.5 & 15.1 & 14.3 & 13.6 & 9.9 & 10.2 \\
\hline 20 & 1 & 0 & -1 & 0 & 540 & 780 & 1320 & 11.8 & 8.4 & 8.7 & 8.1 & 5.6 & 5.9 \\
\hline 21 & -1 & 0 & 1 & 0 & 540 & 720 & 1500 & 7.2 & 6.1 & 5.8 & 5.6 & 4.3 & 4.4 \\
\hline 22 & 1 & 0 & 1 & 0 & 540 & 780 & 1320 & 5.0 & 3.8 & 4.0 & 3.7 & 2.9 & 3.0 \\
\hline 23 & 0 & -1 & 0 & -1 & 480 & 840 & 1620 & 13.2 & 9.9 & 8.5 & 8.1 & 6.1 & 6.4 \\
\hline 24 & 0 & 1 & 0 & -1 & 240 & 240 & 360 & 19.1 & 15.3 & 18.2 & 16.8 & 14.2 & 14.4 \\
\hline 25 & 0 & -1 & 0 & 1 & 960 & 1560 & 2880 & 7.4 & 5.8 & 5.3 & 5.1 & 4.1 & 4.3 \\
\hline 26 & 0 & 1 & 0 & 1 & 480 & 480 & 720 & 10.3 & 8.4 & 9.9 & 9.2 & 7.9 & 8.0 \\
\hline 27 & 0 & 0 & 0 & 0 & 480 & 840 & 1440 & 11.8 & 9.2 & 7.4 & 7.0 & 5.7 & 5.9 \\
\hline
\end{tabular}

Regression models were created by the results of the calculated data processing; they described the relationship between the specific output of manure-bearing wastewater and four independent variable factors. After the insignificant regression coefficients were eliminated, the coded equations of the established models were presented for the farms using different milking installations:

herringbone with rapid exit:

$$
\begin{gathered}
Y_{1}=11.867-2.367 \cdot X_{1}+2.042 \cdot X_{2}-4.833 \cdot X_{3}-3.442 \cdot X_{4}-0.588 \cdot X_{1}^{2}-0.85 \cdot X_{1} \cdot X_{2}+ \\
+1.125 \cdot X_{1} \cdot X_{3}+0.975 \cdot X_{1} \cdot X_{4}-0.975 \cdot X_{2} \cdot X_{3}-0.75 \cdot X_{2} \cdot X_{4}-0.638 \cdot X_{3}^{2}+1.7 \cdot X_{3} \cdot X_{4}+0.6 \cdot X_{4}^{2} . \\
R^{2}=0.998
\end{gathered}
$$


herringbone with regular exit:

$$
\begin{gathered}
Y_{2}=9.356-2.392 \cdot X_{1}+1.858 \cdot X_{2}-3.633 \cdot X_{3}-2.583 \cdot X_{4}-0.458 \cdot X_{1}{ }^{2}- \\
-0.85 \cdot X_{1} \cdot X_{2}+1.1 \cdot X_{1} \cdot X_{3}+0.925 \cdot X_{1} \cdot X_{4}-0.925 \cdot X_{2} \cdot X_{3}-0.7 \cdot X_{2} \cdot X_{4}- \\
-0.521 \cdot X_{3}{ }^{2}+1.275 \cdot X_{3} \cdot X_{4}+0.404 \cdot X_{4}{ }^{2} . \\
R^{2}=0.997
\end{gathered}
$$

parallel with one exit:

$$
\begin{gathered}
Y_{3}=8.04-1.95 \cdot X_{1}+3.191 \cdot X_{2}-3.5 \cdot X_{3}-2.325 \cdot X_{4}-1.5 \cdot X_{1} \cdot X_{2}+1.702 \cdot X_{2}{ }^{2}- \\
-1.55 \cdot X_{2} \cdot X_{3}-1.275 \cdot X_{2} \cdot X_{4} \cdot R^{2}=0.956
\end{gathered}
$$

parallel with two exits:

$$
\begin{aligned}
Y_{4}=7.593-1.942 \cdot X_{1} & +2.858 \cdot X_{2}-3.242 \cdot X_{3}-2.142 \cdot X_{4}-1.45 \cdot X_{1} \cdot X_{2}+1.515 \cdot X_{2}^{2}- \\
& -1.425 \cdot X_{2} \cdot X_{3}-1.15 \cdot X_{2} \cdot X_{4} \cdot R^{2}=0.954 ;
\end{aligned}
$$

carousel with the operator outside the platform:

$$
\begin{gathered}
Y_{5}=5.728-1.917 \cdot X_{1}+2.575 \cdot X_{2}-2.5 \cdot X_{3}-1.792 \cdot X_{4}-1.2 \cdot X_{1} \cdot X_{2}+0.725 \cdot X_{1} \cdot X_{3}+ \\
+0.725 \cdot X_{1} \cdot X_{4}+1.635 \cdot X_{2}{ }^{2}-1.25 \cdot X_{2} \cdot X_{3}-1.075 \cdot X_{2} \cdot X_{4}+0.825 \cdot X_{3} \cdot X_{4}+0.785 \cdot X_{4}{ }^{2} \\
R^{2}=0.982
\end{gathered}
$$

carousel with the operator in the centre:

$$
\begin{gathered}
Y_{6}=5.917-1.9 \cdot X_{1}+2.533 \cdot X_{2}-2.6 \cdot X_{3}-1.85 \cdot X_{4}-1.175 \cdot X_{1} \cdot X_{2}+0.725 \cdot X_{1} \cdot X_{3}+0.7 \cdot X_{1} \cdot X_{4}+ \\
+1.619 \cdot X_{2}^{2}-1.25 \cdot X_{2} \cdot X_{3}-1.075 \cdot X_{2} \cdot X_{4}+0.875 \cdot X_{3} \cdot X_{4}+0.794 \cdot X_{4}^{2} \cdot R^{2}=0.984,
\end{gathered}
$$

where $R^{2}$ is the determination coefficient.

Multiple regression analysis of the obtained data showed that the specific output of manurebearing wastewater was most affected by the following factors: herringbone installation - the number of floor washings $X_{3}$ and the milking time $X_{4}$; parallel and carousel installations - the number of floor washings $X_{3}$ and the milking installation size $X_{2}$. For carousel installation the effect of these factors was approximately the same. With the smaller technological group size, the specific amount of manure-bearing wastewater generated in the milking parlour decreased, but with the smaller number of milking units (stalls), it increased. With the longer milking time of the herd it decreased due to the bigger number of cows served per unit of area, which required cleaning.

The regression equation for determining the maximum dairy herd size, which depends on the technological group size $\left(X_{1}\right)$, the milking installation size $\left(X_{2}\right)$ and the milking time of the herd $\left(X_{4}\right)$, may be presented in the coded form after the insignificant regression coefficients are eliminated:

- for herringbone installation:

$$
G_{1}=531.111-180.0 \cdot X_{2}+175.0 \cdot X_{4}-60.0 \cdot X_{2} \cdot X_{4} R^{2}=0.985 ;
$$

- for parallel installation:

$$
G_{2}=797.778-420.0 \cdot X_{2}+245.0 \cdot X_{4}-120.0 \cdot X_{2} \cdot X_{4} R^{2}=0.988 ;
$$

- for carousel installation:

$$
G_{3}=1368.89-45.0 \cdot X_{1}-820.0 \cdot X_{2}+425.0 \cdot X_{4}-225.0 \cdot X_{2} \cdot X_{4} R^{2}=0.993 .
$$

The milking installation size, the milking time, and their interaction demonstrated the greatest effect on the calculation results. With an increase in the milking installation size and the milking time, the number of cows that could be milked on the milking installation under consideration increased.

The search for optimal technological parameters of the farm and the milking parlour in terms of the minimum output of manure-bearing wastewater by the non-linear programming method in a coded form will look like:

$$
\begin{aligned}
& Y_{s p}=f\left(X_{0}, X_{1}, X_{2}, X_{3}, X_{4}\right) \rightarrow \min ; G=f\left(X_{1}, X_{2}, X_{4}\right) ; \\
& -1 \leq X_{1} \leq 1 ;-1 \leq X_{2} \leq 1 ;-1 \leq X_{3} \leq 1 ;-1 \leq X_{4} \leq 1
\end{aligned}
$$

The solving procedure of the optimisation problem allows to find the optimal value of the objective function by varying the values of the influencing factors. To narrow the set of values used in 
the model, restrictions on the values of variables and final factors were applied [17]. When decoding the obtained results, it should be remembered that the factors of the technological group size and the number of floor washings are to be the whole numbers, and the size of herringbone and parallel installations is usually an even number.

The optimisation problem (15) was solved in EXCEL with the use of mathematical models (6) (11) and (12) - (14). The values of the factors providing the minimum specific output of manurebearing wastewater were obtained for two-time milking of the herd of 600 heads with limited milking time of 5 hours. Coded values were converted into real ones by the method in [17].

The optimisation problem solution by mathematical models (6) - (11) and (12) - (14) for the considered milking installations is shown in Fig.1.

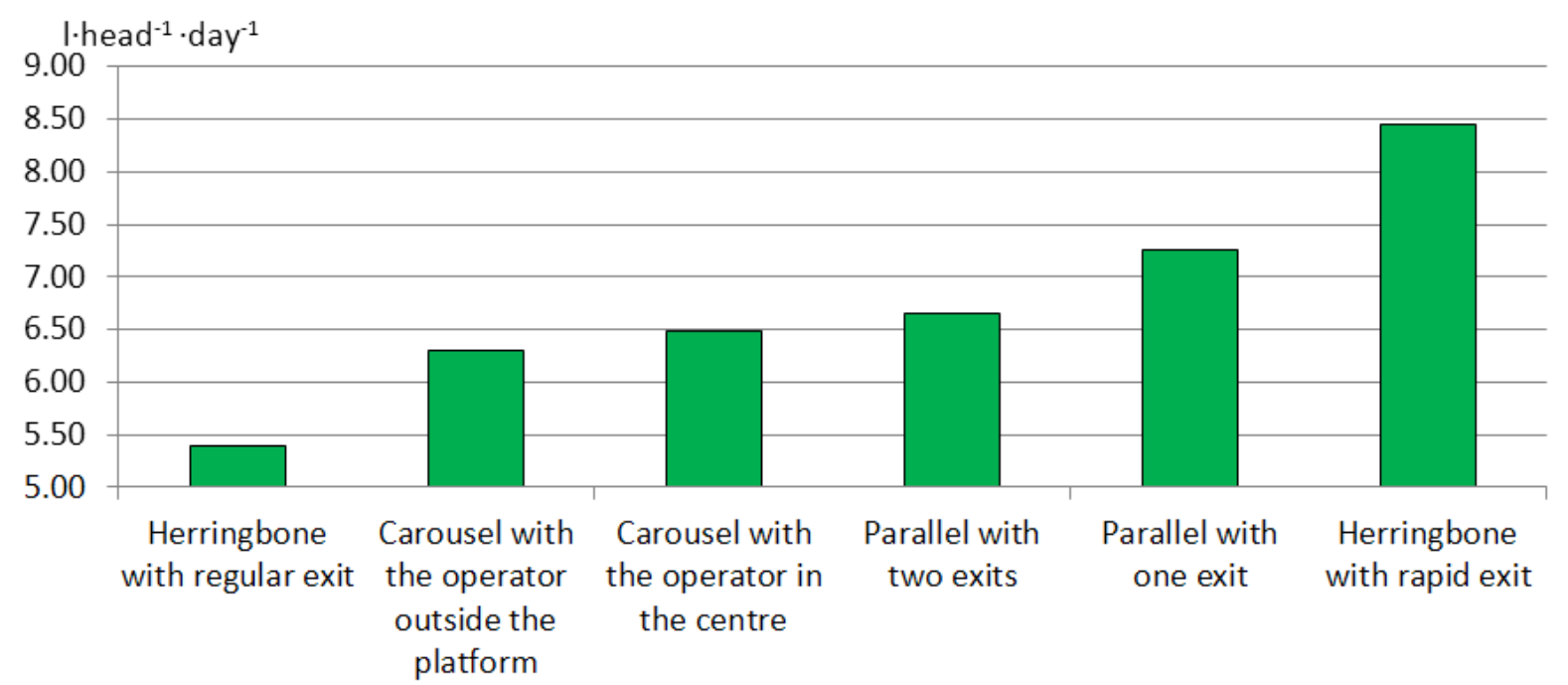

Fig. 1. Optimisation problem solution for different types of milking installations

Comparing the data obtained, when solving the optimisation problem for each milking installation type, the conclusion was that the minimum specific output of manure-bearing wastewater (5.4 1. head ${ }^{-1} \cdot$ day $^{-1}$ ) would be obtained on the herringbone installation with regular exit, with the technological group size being 60 heads and the number of milking units being 40 .

\section{Conclusions}

The approximate daily output of manure-bearing wastewater from the milking parlour may be calculated for a particular milking installation type by the technological group size $\left(X_{1}\right)$, milking installation size $\left(X_{2}\right)$, number of floor washings $\left(X_{3}\right)$ and the milking time of the cow herd $\left(X_{4}\right)$.

Solution of the optimisation problem will allow to calculate the technological parameters of the farm and the milking parlour in terms of the minimum output of manure-bearing wastewater. This, in its turn, will give an opportunity to reduce the production waste already at the conceptual designing stage and, consequently, to decrease the anthropogenic load on the environment, as well as to estimate the required storage capacity and the land area for manure-bearing wastewater application.

\section{References}

[1] Georgiev D. Comparative analysis of plane geometric parameters of various types of cow milking parlors. Agricultural Science and Technology, vol. 8, No 4, 2016, pp. 318-322.

[2] Gaworski M., Kamińska N., Kic P. Evaluation and optimization of milking in some Polish dairy farms differed in milking parlours. Agronomy Research. 2017, 15(1), pp. 112-122.

[3] Kic P. Mathematical model for optimal arrangement of milking parlor. AgricEngInt: CIGR Journal, Special issue 2015: 18th World Congress of CIGR: 71-79.

[4] Georgiev D., Peytchev K., Dimova V., Georgiev R., Uzunova K., Stoyanova V., Tosheska M.. Analysis of Costs for Construction of Milking Parlours of Various Designs. Agricultural University of Tirana, 2016, pp. 54-64.

[5] John P. Chastain, Keri B. Cantrell, and Kathy P. Moore. Composition and Settling Characteristics of Milking Center Wastewater: A Case Study. ASAEAnnual International Meeting. 2005. 
[6] Неверова О.П., Ильясов О.Р., Донник И.М., Шаравьев П.В. Технология подготовки сточных вод животноводческих хозяйств для их использования в качестве питательного субстрата. (The technology of preparing waste water for use as a nutritious substratum on agricultural enterprises). Agrarian Bulletin of the Urals:АграрныйвестникУрала. No 10 (152), 2016. pp. 31-36.(In Russian).

[7] Гордеев В.В., Миронова Т.Ю., Хазанов В.Е., Гордеева Т.И. Оценка влияния технологических решений доильно-молочного блока на выход навозосодержащих стоков (Influence assessment of technological solutions for milking and milk handling block on manurebearing wastewater amount). Technologies, machines and equipment for mechanised crop and livestock production: Технологии и технические средства механизированного производства продукции растениеводства и животноводства. 2018. No 2 (95). pp. 167-173. DOI 10.24411/0131-5226-2018-10044. (In Russian).

[8] Миронова Т.Ю., Гордеев В.В., Гордеева Т.И., Миронов В.Н. Влияние планировочных решений коровников на количество навозосодержащих стоков (Effect of barn layout solutions on manure-bearing waste water amount). Molochnokhozyaistvenny Vestnik: Молочнохозяйственный вестник. 2016. № (24). pp. 92-98. (In Russian).

[9] Gaworski M, Rocha A.G.F. Effect of management practices on time spent by cows. Proc. 15th Int. Sc. Conf. «Engineering for Rural Development». Jelgava, 2016, vol. 15, pp. 1300-1304.

[10] Milking center wastewater guidelines a companion document to Wisconsin NRCS Standard 629. June 2009. [online]. [30.11.2018]. Available at: www.wi.nrcs.usda.gov/news/629guide.html.

[11]Гордеев В.В., Миронова Т.Ю., Миронов В.Н. Методика определения количества навозосодержащих стоков доильных залов (Method to determine the amount of manurebearing wastewater from milking parlours). Technologies, machines and equipment for mechanised crop and livestock production: Технологии и технические средства механизированного производства продукции растениеводства и животноводства. 2018. No 4 (97). pp. 241-250. (In Russian).

[12]РД-АПК 1.10.01.01-18 Методические рекомендации по технологическому проектированию ферм и комплексов крупного рогатого скота (Management Directive for Agro-Industrial Complex "Recommended Practice for Engineering Designing of Cattle Farms and Complexes). Moscow: Rosinformagrotekh: M. Росинформагротех. 2018. 166 p. (In Russian).

[13]РД-АПК 1.10.15.02-17 Методические рекомендации по технологическому проектированию систем удаления и подготовки к использованию навоза и помета (Management Directive for Agro-Industrial Complex "Recommended Practice for Engineering Designing of Systems for Animal and Poultry Manure Removal and Pre-application Treatment", Moscow: Rosinformagrotekh: M. Росинформагротех. 2017. 173 p. (In Russian).

[14] Тимошенко В., Музыка А., Москалёв А., Ковалевский И. Сохраняем здоровье копыт (Maintaining hoof health). 2015. No 1. pp. 33-35. (In Russian).

[15] Тимошенко В., Музыка А., Москалёв А., Кирикович С. Ванны для копыт (Bathsforhooves). Animal husbandy of Russia: Животноводство России. 2016.No6. pp. 37-38.(In Russian)

[16]Гордеев В.В., Хазанов В.Е., Собовая С.В. Методика расчета технологических площадей доильных залов с установками типа «Ёлочка» и «Параллель» (Calculation method of technological area of milking parlours with "herringbone" and "parallel" milk lines). Технологии и технические средства механизированного производства продукции растениеводства и животноводства: Technologies, machines and equipment for mechanised crop and livestock production 2018. No 3 (96). pp. 186-193. DOI 10.24411/0131-5226-2018-10072. (In Russian).

[17]Валге А.М., Джабборов Н.И., Эвиев В.А. Основы статистической обработки экспериментальных данных при проведении исследований по механизации сельскохозяйственного производства с примерами на STATGRAPHICS и EXCEL (Fundamentals of statistical processing of experimental data for research in mechanisation of agricultural production with examples in STATGRAPHICS and EXCEL). Saint Petersburg; Elista: Kalmyk Univ. Publ.: СПб; Элиста: Изд-во Калм. Ун-та, 2015. 140 р. (In Russian). 